\title{
ANALYSIS OF DENICKELIFICATION PHENOMENON ON HEAT EXCHANGER TUBE
}

\section{ANALISIS TENTANG FENOMENA TERJADINYA DENIKELIFIKASI PADA TUBE ALAT PENUKAR KALOR}

\author{
Amin Suhadi, Eka Febriyanti, Laili Novita Sari \\ Balai Besar Teknologi Kekuatan Struktur (B2TKS) - BPPT \\ Kawasan Puspitek Serpong Tangerang 15314 \\ e-mail : amin.suhadi@bppt.go.id, eka.febriyanti@bppt.go.id, laili.novita@bppt.go.id
}

\begin{abstract}
Denickelification is a common phenomenon which occurs for alloy metal containing sufficient amounts of Nickel when it is exposed at high temperature in long time periode. One of the exampl is heat exchangers tube. The heat exchanger is a part of a processing unit that has a function of transfering heat from hot fluid to colder fluid through the combined mechanisms of conduction and convection. Failure on heat exchanger could affect to all of the processing systems. In this research, a leakage heat exchanger tube is investigated by failure analysis methods to find the root cause of failure. Several tests and examinations such as fractography, metallography examinations, SEM and EDS, hardnes as well as chemical compositions test are carried out to this tube to obtain detailed information for further analysis. The result of this reseach shows that some $\mathrm{Cu}$ residue, $\mathrm{Ni}$, aggressive/corrosive ion such as $\mathrm{Cl}^{-}$and $\mathrm{S}^{2-}$ at the leakage area of the heat exchanger tube is found. This evidence indicated that denickelification occurred on the inner surface of the heat exchanger tube caused by the potential difference between $\mathrm{Ni}^{2+}$ ion and $\mathrm{Cu}^{2+}$ ion to form a galvanic cell. Furthermore, since the tube is flown by fluid material which contains aggressive/corrosive ions such as $\mathrm{Cl}^{-}$ion and $\mathrm{S}^{2-}$ then pitting corrosion on the inner surface of the tube is formed. This mechanism had been taken place continuously during operation of the heat exchanger and pitting corrosion keep growing until the tube leaks.
\end{abstract}

Key words: heat exchanger, tube, denickelification, pitting corrosion

\section{Abstrak}

Denikelifiasi adalah fenomena yang umum terjadi pada paduan logam yang mengandung sejumlah Nikel yang mengalami pemanasan untuk waktu yang cukup lama. Salah satu contohnya adalah tube alat penukar kalor (APK). APK adalah salah satu peralatan pada unit proses yang berfungsi untuk memindahkan kalor dari fluida panas ke fluida lain yang lebih dingin melalui kombinasi mekanisme perpindahan panas konduksi dan konveksi. Kegagalan pada APK bias mengakibatkan proses produksi berhenti dan menimbulkan kerugian yang cukup besar. Pada penelitian ini dilakukan investigasi kebocoran tube APK menggunakan metode analisa kerusakan guna mendapatkan penyebab utama terjadinya kebocoran tersebut. Berbagai pengujian dan pemeriksaan telah dilakukan yaitu, fraktografi, metalografi, analisa dengan SEM dan EDS, pengujian kekerasan dan analisa komposisi kimia untuk mendapatkan informasi yang lebih rinci sebagai bahan analisa yang lebih dalam. Hasil dari penelitian ini menunjukkan bahwa pada 
daerah kebocoran ditemukan residu $\mathrm{Cu}$, Ni dan ion agresiv $\mathrm{Cl}$ dan $S^{2-}$. Bukti-bukti ini menunjukkan bahwa telah terjadi denikelifikasi pada permukaan dalam tube yang disebabkan oleh perbedaan potensial antara ion $\mathrm{Ni}^{2+}$ dan ion $\mathrm{Cu}^{2+}$ membentuk sel galvanic. Karena selama beroperasi tube terus dialiri oleh fluida yang mengandung ion agresif/korosif $\mathrm{Cl}$ dan $\mathrm{S}^{2-}$ maka terbentuklah korosi sumuran di permukaan dalam tube. Mekanisme ini berlangsung terus menerus hingga tube mengalami kebocoran.

Kata Kunci :alat penukar kalor, kebocoran tube, denikelifikasi, korosi sumuran

Diterima (received) : 11 Mei 2018, Direvisi (revised ) : 11 Juli 2018

Disetujui (accepted) : 18 Juli 2018

\section{PREFACE}

The heat exchanger is an important equipment in oil and gas processing system. The function of the heat exchanger is to transfer thermal energy from one fluid (hot fluid) to another (cold fluid) through the tubes by conduction and convection mechanism [13]. In the oil and gas production system, heat exchanger (HE) is used to support the whole processing sequence of production from raw material to the final product. The most commonly used of HE in oil and gas industry is shell and tubes type because of several advantages such as: providing large heat transfer surface in a relatively small volume, good for high pressure operation, simple construction, relatively small space needed, and easy to be operated. The most advantages are this type of heat exchanger can be made by many kinds of materials correspond to the fluids, operational temperature and pressure ${ }^{[1-3]}$.

In most of oil and gas processing unit, a common material for HE tubes is made of Cupronickel (Cu-Ni 90/10 and $\mathrm{Cu}-\mathrm{Ni}$ 70/30) alloys, which can be operated in the marine atmosphere. Cupronickel material has high corrosion resistance, good mechanical properties, high heat conductivity, and has good fouling resistance ${ }^{[4]}$. In this research, detail examinations are conducted for $\mathrm{HE}$ shell and tubes which are operated in an oil refinery system but leaks during normal operation. As a result, the whole refinery process was shut down and in order to make an exact follow up the action, deep failure analysis should be done as soon as possible.

The purpose of this research is to find out the root cause of failure including the mechanism of such failure was initiated and how the failure propagated so that similar failure can be prevented in the future.

\section{MATERIAL AND METHOD}

\section{Material}

The material of this research is taken from two leakage heat exchanger tubes made of Copper alloy which contains about $30 \%$ weight Nickel element. Both tubes are cut from the same row of heat exchanger side by side in a straight position.

The exact position of both leakage tubes in the heat exchanger can be seen in Figure 1.

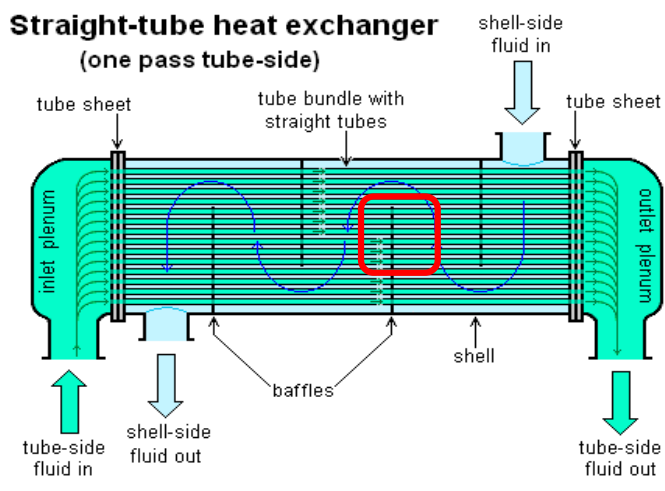

Figure 1.

The position of the leakage tube on $\mathrm{HE}^{[1]}$.

Detail parameters are listed in Table 1.

The photograph of two leakage heat exchanger tubes after cut from tubes bundle can be seen in Figure 2.

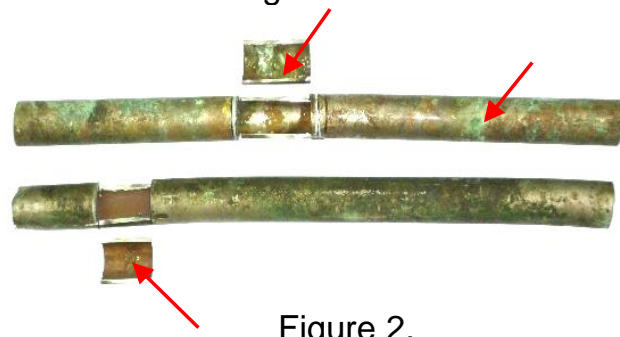

Photograph of leakage straight Exchanger Tubes and location of of cutting for samples of further examinations. Red arrows indicate the presence of deposits on the inner and outer surfaces. 
Two small pieces are cut as samples for further examination such fractography, metallography and Scanning Electron Microscopy examinations. Locations of cutting are exactly on the area of leakage. It can be seen from this photo that some deposits are found either on the inner surface or on the outer surface.

\section{Material Specification and operational conditions of tubes investigated.}

Technical data, main operational parameters and actual conditions of the straight tubes investigated can be seen in Table 1. In addition, the position of material in the binary phase diagram between $\mathrm{Cu}$ and $\mathrm{Ni}$ is shown in the red doted line in Figure 3.

Table 1.

Spesification of tube Material and Operational condition of Heat Exchanger Tubes

\begin{tabular}{ll}
\hline Name of unit & Heat exchanger \\
\hline Location of tubes & Straight tubes \\
HE tubes material & Cu-Ni alloy \\
& $(\mathrm{Cu}-30 \mathrm{Ni})$ \\
Design pressure & $\left(\mathrm{kg} / \mathrm{cm}^{2}\right)$ \\
shell side & 32,3 \\
tube side & 7 \\
Design temperature & $\left({ }^{\circ} \mathrm{C}\right)$ \\
shell side & 163 \\
tube side & 66 \\
Internal fluid & \\
shell side & Hydrogen gas, \\
& Hydrocarbon, \\
tube side & water \\
\hline
\end{tabular}

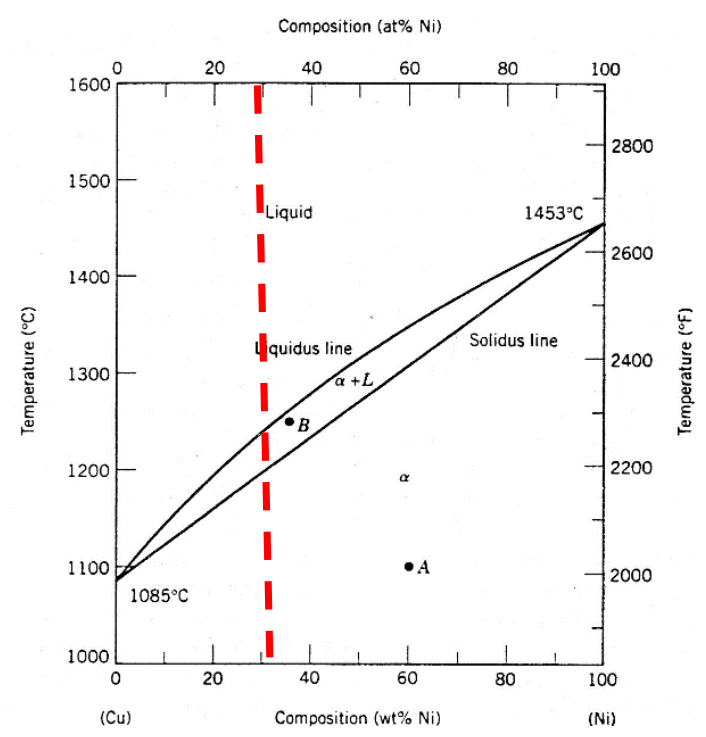

Figure 3.

Binary phase diagram of $\mathrm{Cu}-\mathrm{Ni}{ }^{[5]}$

\section{Research Method}

Method of this research is implemented root cause analysis or fish bone diagram for failure analysis. All of the posssible causes to failure are observed such as wrong design, material out of specification, material defect, bad manufacturing process, wrong assembly work, wrong operational procedure and also bad maintenance program. All of those possibilities are observed, and then with scientific evidence found from testings and examinations, the root cause of failue can be decided. Step by step examinations and tests are described in Figure 4.

Detail examinations and tests consist of observation and data collection concern with cronology of operation until fail, visual inspection, macro fractography analysis, micro structure examinations, grain boundary measurement and hardness testing.

Another specimen is then selected for chemical composition analysis using an optical emission spectrometer. The specific specimen is also selected for micro fractography analysis, the examination is focused on the area of the hole and its surroundings. Micro fractography is conducted by Scanning Electron Microscopy (SEM) which is connected with Energy Dispersive Spectroscopy (EDS) for further chemical analysis of deposit.

The first step of examination that has been done is visual inspection. The purpose of this inspection is to identify the exact position of failure related to the factors which may influence the formation of initial failure. This inspection is also observing the type of failure which can give valuable information for analysis.

The following examination is macro fractography analysis. This analysis is conducted by studying the contour of the surface fracture by stereo microscopy so that the point of initial fracture or failure can be determined and then from this point intensive suitable examinations are done.

When the initial failure has been found, further examinations are focused on this area including a hardness test, SEM and metallographic examination. Hardness tes is conducted to verify the current hardness properties to the available specification. The points of the test are selected in the area surrounding the failure/hole and compared with another area which is not damage. Method of testing is macro hardness vickers with $5 \mathrm{kgf}$ load refer to SNI 19-0409-1989 standard. 
Metallographic examinations are conducted to evaluate the alloy phase that has been formed and also to find any micro defect, micro crack or inclusions that may occur in this tube. The current condition of the microstructure is compared with a normal microstructure in the reference book for the same alloy. Therefore, any deviation of the microstructure can be identified and could give additional evidence for analysis to find the root cause of failure. Together with microstructure examination, grain size measurement can also be done to find evidence of overheating that can be indicated by the occurance of grain growth.

Chemical composition test using Optical Emission Spectrometric (OES) is the following step that conducted for checking the latest composition of the leakage tubes or to verify its composition with standard specification ASTM B-466 (C 71500).

To obtain more detail information concern with contour and conditions of failure surface, micro fractography analysis is conducted using Scanning Electron Microscopy (SEM) which can explore the image in three dimensions with higher magnification. SEM which is connected with EDS (Energy Dispersive Spectrometer) has the capability to detect and identify more detail for suspicious object, inclusion or any other elements on the surface. Therefore, aggressive ion which has an important role in the cause of failure can be analysed.

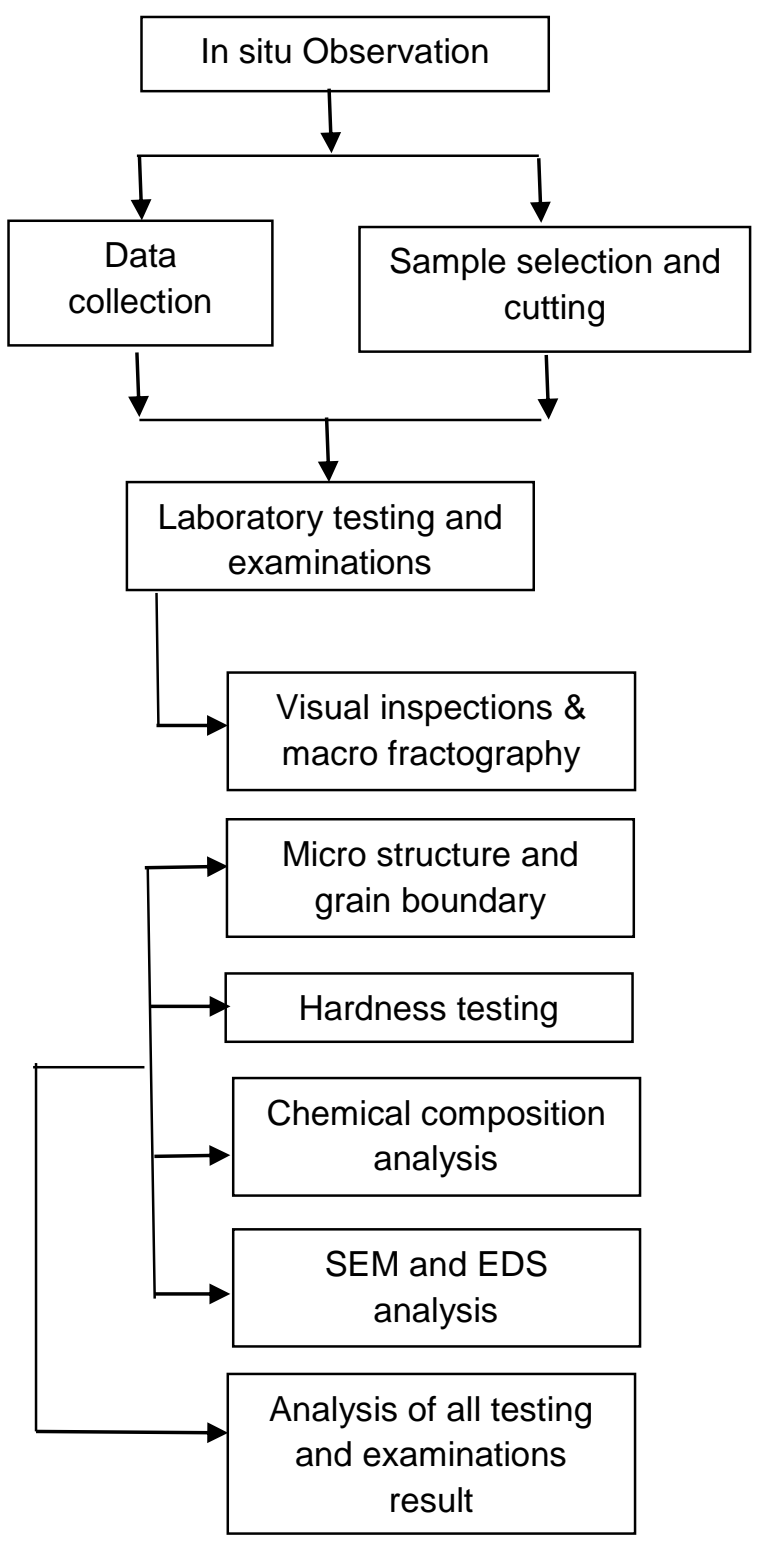

Figure 4.

Flow chart of research steps for leak heat exchanger tube. 


\section{RESULT AND DISCUSSION}

\section{Visual and Macro Fractography}

The resultz of visual and macro fractography examination on the specimens show that some pittings and holes are found on each tube investigated. All holes are initiated from inside surface to outer surface (Figure 5 to Figure 9). This result also shows the evidence of deposit that sticks to either the inner or outer surface of the tubes. The colour of deposit which presence around the pits or holes is green (Figure 5 to 9).

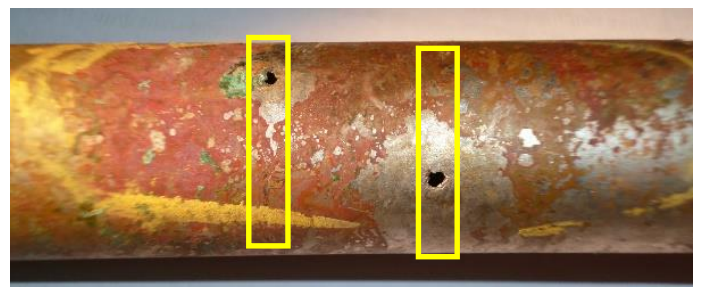

Location 1 Location 2 Figure 5.

Holes and deposit on straight heat exchanger tube and location of specimens taken for further examinations and testings.

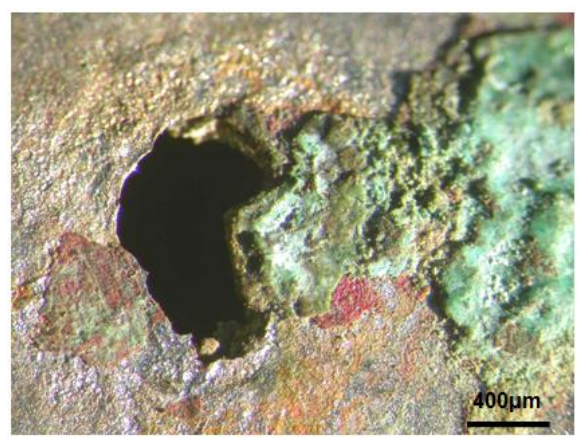

Figure 6.

Hinger exposure on location 1, show the presence of green deposit on the outer surface around the hole.

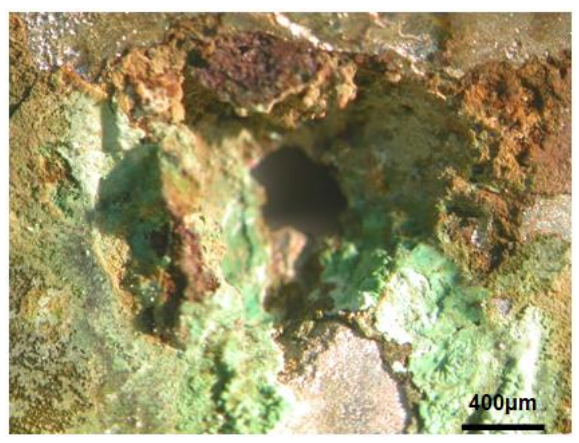

Figure 7.

Higher exposure on location 1 from the inner surface, shows green deposit around the hole.

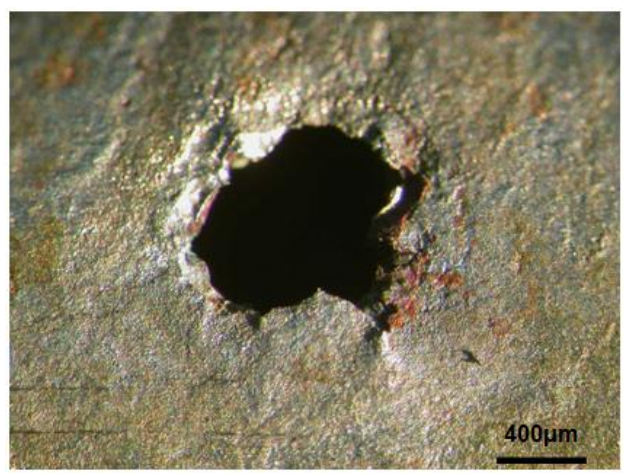

Figure 8.

Higher exposure at location 2 on the outer surface, shows the hole with little deposit.

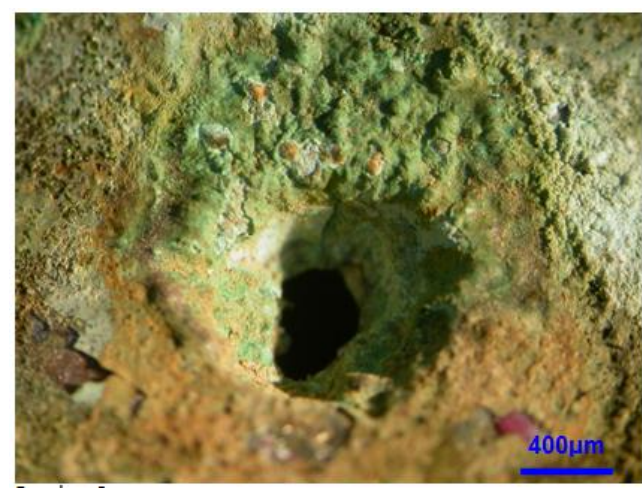

Figure 9.

Higher exposure on location 2 from the inner surface, shows green deposit around the hole.

\section{Metallography examination result}

Metallography examinations which are focused on holes surrounding area of location 1 and 2 can be seen in figure 10 to 15 . The specimens are cut in cross section near the hole such as presented in Figure 10.

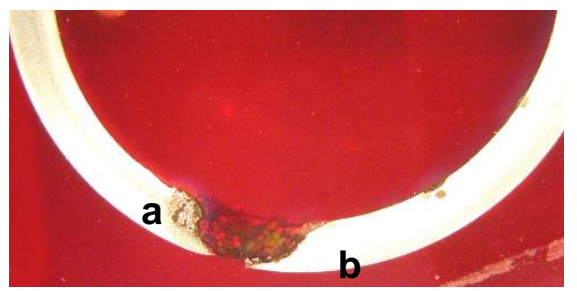

Figure 10.

Cross section of the sample for metallographic analysis on location 1. (a) and (b) are points for examinations 


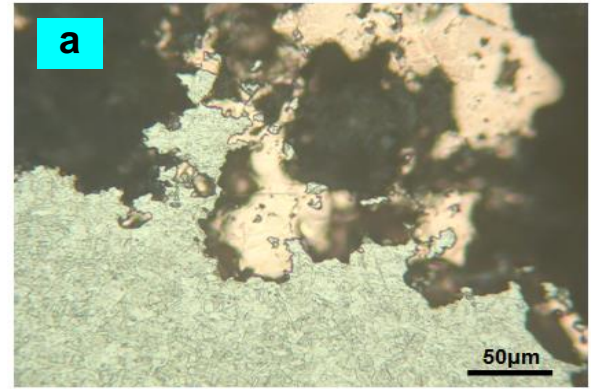

Figure 11.

Metallography result on area (a) shows $\mathrm{Cu}$ deposit that sticked on the microstructure.

Etched by: $\mathrm{K}_{2} \mathrm{Cr}_{2} \mathrm{O}_{7}$

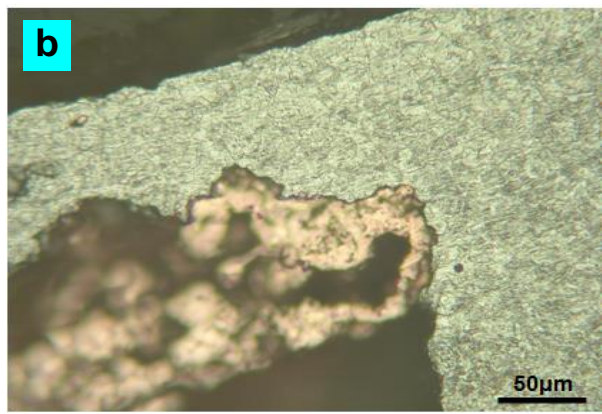

Figure 12.

Metallography result on area (b) shows the Cu deposit that sticked on the microstructure.

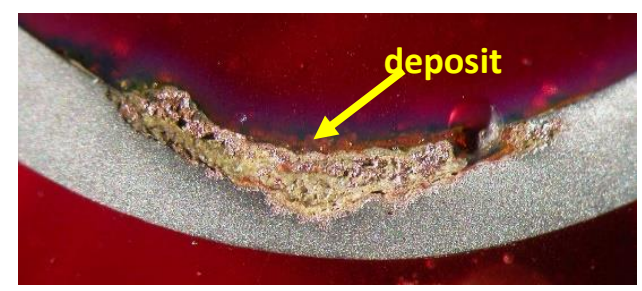

Figure 13.

Deposit is clearly seen on the inner surface of a cross section of the sample on location 2. This sample is taken for metallographic analysis.

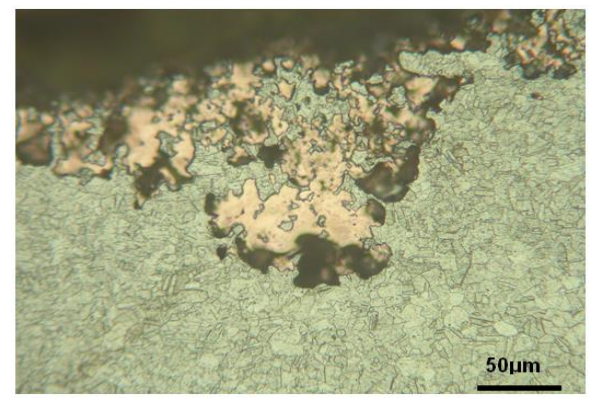

Figure 14.

The metallographic result on the cross section of the sample on location 2 shows $\mathrm{Cu}$ deposit on microstructure, as result of denickelification.

Etched by: $\mathrm{K}_{2} \mathrm{Cr}_{2} \mathrm{O}_{7}$

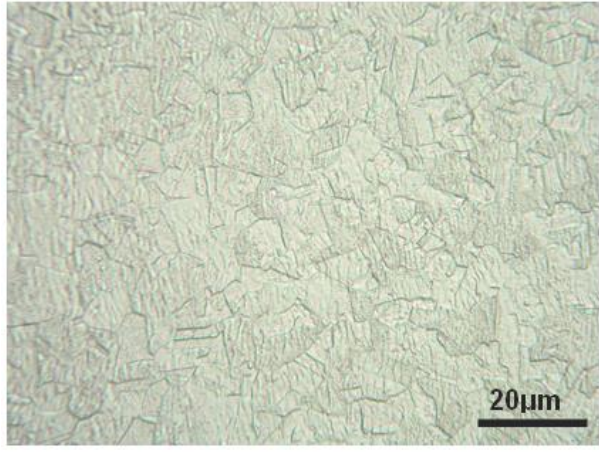

Figure 15.

The microstructure of a normal tube is $\alpha$ -

phase with austenitic structure. No inclusions or deposits are found. This sample is taken $10 \mathrm{~cm}$ from the hole and etched by $\mathrm{K}_{2} \mathrm{Cr}_{2} \mathrm{O}_{7}$

The purpose of metallographic analysis on location 1 and 2 is to confirm the result of observation on macro fractography concern with the presence of pitting, hole and deposit. The result of metallogrphic examination also confirms that all of the pitting, hole and deposits are existing. The deposit with green and brown colour is identified as residual Copper which is a result of the denickelification process of tube material $\mathrm{Cu}$ $30 \mathrm{Ni}$.

Examination result of the normal tube that taken from a location away from the hole has no deposit, no crack and no inclusions. The microstructure is typical of Cupro Nickel structure such as $\alpha-F C C$ (austenitic) with twin crystal of Cu-Ni (Figure 3).

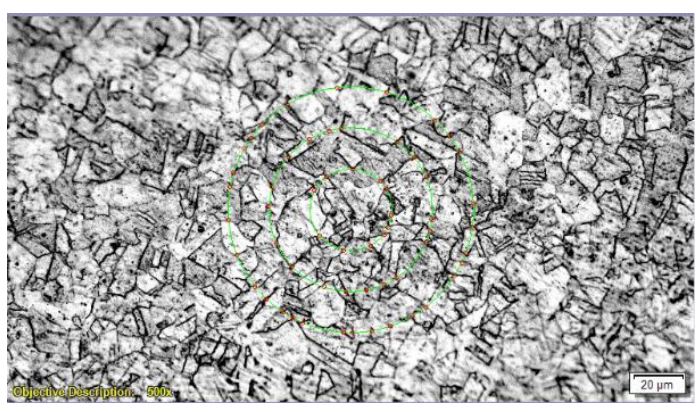

Figure 16.

Grain size measurement result of the tube by Intercept Heyn method shows that average grain diameter is $12,17 \mu \mathrm{m}$

The result of grain size measurements refers to ASTM E-112-13[7] standard (Figure 16) show that the tube investigated has average grainsize of $12,17 \mu \mathrm{m}$. While measurement on Copper deposit grain diameter has a value much higher than normal grain size $(37 \mu \mathrm{m})$. 
Although exposure of this material to a high temperature for a long time could promote grain growth the increasing of grain size has never been such high $(12,17 \mu \mathrm{m}$ grows to 37 $\mu \mathrm{m})$. The only possibility to obtain the grain size much higher then normal grain is by melting and then followed by solidification mechanism. This evidence confirms that the red colour which is existed on microstructure is not grain growth of Copper base metal but Copper deposit which is coming from the denickelification process and then redeposits to the tube surface.

\section{Hardness Test Result}

Hardness test result that conducted on the straight tube to evaluate the current hardness value can be seen in Table 2. Hardness test is conducted using macro hardness vickers with $5 \mathrm{kgf}$ load.

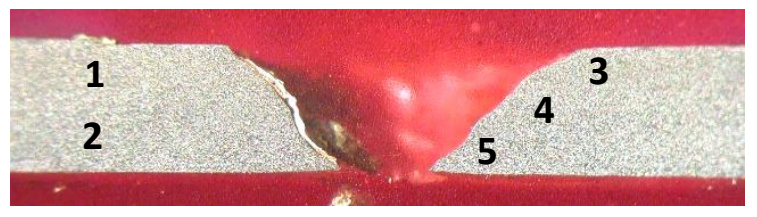

(a)

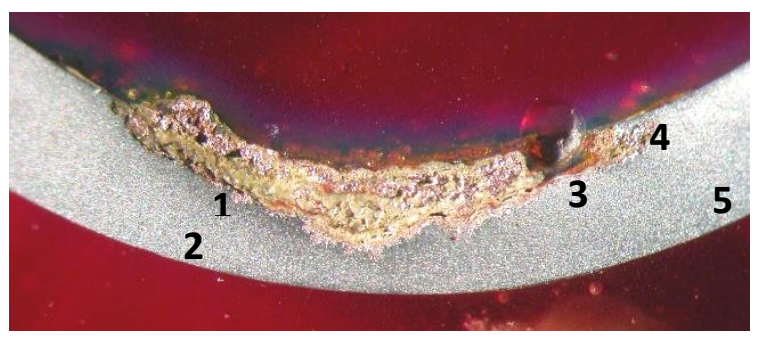

(b)

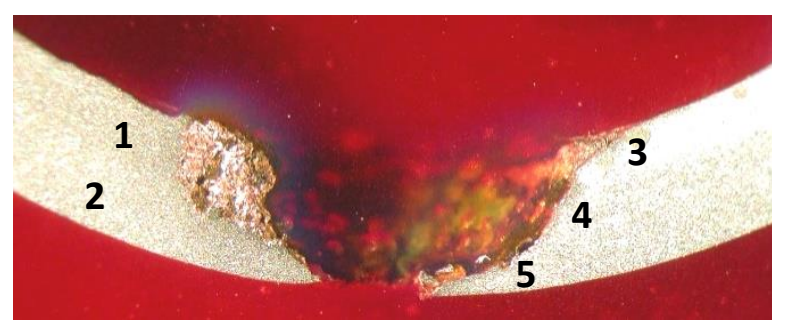

(c)

Figure 17.

Points of indentations for hardness test of cross section tube around the hole. Refer to Figure 5, (a) location 1, (b) and (c) location 2
Table 2.

Hardness test result on the cross section of tube

\begin{tabular}{ccccc}
\hline No. & \multicolumn{4}{c}{$\begin{array}{c}\text { Vickers Hardness Value } \\
\text { (load =5 kgf) }\end{array}$} \\
\cline { 2 - 5 } & $\mathrm{a}$ & $\mathrm{b}$ & $\mathrm{c}$ & $\begin{array}{c}\text { ASTM } \\
\text { B-466 [8] }\end{array}$ \\
\hline 1 & 97,2 & 112,4 & 102,3 & \\
2 & 96,5 & 110,0 & 100,9 & \\
3 & 86,7 & 102,3 & 114,0 & $\mathbf{8 0 - 1 2 0}$ \\
4 & 94,1 & 100,2 & 115,6 & \\
5 & 86,7 & 95,9 & 112,4 & \\
\hline Average & 92,2 & 104,1 & 109 & \\
\hline
\end{tabular}

Hardness testing result indicated that the tube investigated has average hardness value in accordance with ASTM B-466 standard for $70 \mathrm{Cu}-30 \mathrm{Ni}$ (Copper-Nickel alloy) ${ }^{[4]}$.

\section{Chemical composition examinations}

Chemical composition test result of exchanger tube compared with its standard specification can be seen in Table 3. This result indicated that the tube investigated is in accordance with ASTM B-466 for $70 \mathrm{Cu}-30 \mathrm{Ni}$

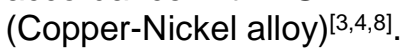

Table 3.

Chemical composition testing result of heat exchanger tube

\begin{tabular}{|c|c|c|c|}
\hline \multicolumn{4}{|c|}{ Straight Heat Exchanger Tube } \\
\hline \multicolumn{2}{|c|}{ Tube investigated } & \multicolumn{2}{|c|}{ ASTM B-466[8] } \\
\hline Element & $\% \mathrm{wt}$ & element & $\% \mathrm{wt}$ \\
\hline $\mathrm{Cu}$ & 69,4 & $\mathrm{Cu}$ & Rem. \\
\hline $\mathrm{Zn}$ & 0,0407 & $\mathrm{Zn}$ & Max. 1,0 \\
\hline $\mathrm{Pb}$ & $<0,200$ & $\mathrm{~Pb}$ & - \\
\hline Sn & 0,0148 & Sn & - \\
\hline $\mathrm{Mn}$ & 0,556 & $\mathrm{Mn}$ & Max. 1,0 \\
\hline $\mathrm{Fe}$ & 0,590 & $\mathrm{Fe}$ & $0,4-1,0$ \\
\hline $\mathrm{Ni}$ & 29,3 & $\mathrm{Ni}$ & $29,0-33,0$ \\
\hline
\end{tabular}

\section{The result of SEM and EDS examinations}

The result of SEM examinations on the surface of the hole of leakage tube shows that this area is covered by deposit (Figure 18). Further examination on this deposit using Electro dispersive spectrometer (EDS) which is shooting on a small spot of deposit (Figure 19) indicated the presence of $\mathrm{Cu}(31,81 \%)$ and $\mathrm{Ni}(6,99 \%)$. Moreover, this analysis also confirm the existence of agressiv / corrosive ion such as $\mathrm{S}^{2-}(0,09 \%)$ and $\mathrm{Cl}^{-}(10,22 \%)$ (Table 4). 


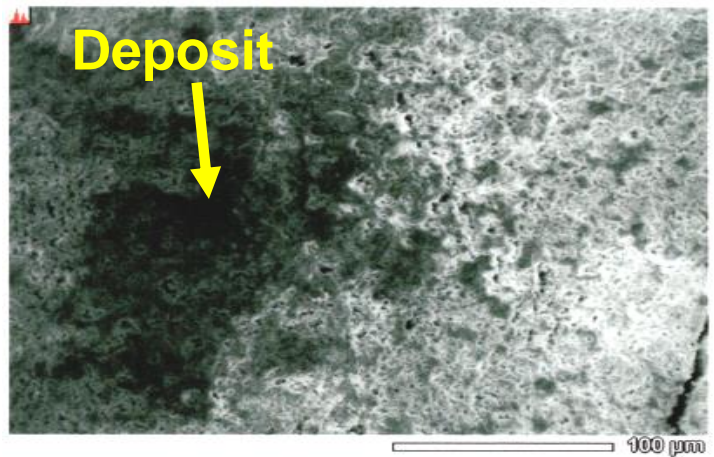

Figure 18.

SEM photograph of hole surface which indicated that this area is covered by deposit

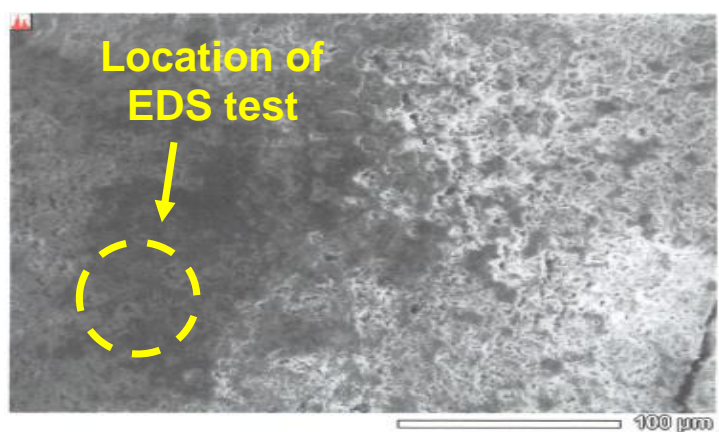

Figure 19.

Location of a spot for examination by EDS

Table 4.

The composition of deposit taken by EDS on the surface around the hole.

\begin{tabular}{cccc}
\hline Element & wt \% & Element & wt \% \\
\hline $\mathrm{C}$ & 18,61 & $\mathrm{Ni}$ & 6,99 \\
$\mathrm{O}$ & 32,06 & $\mathrm{Cu}$ & 31,81 \\
$\mathrm{~S}$ & 0,09 & & \\
$\mathrm{Cl}$ & 10,22 & & \\
$\mathrm{Fe}$ & 0,21 & & \\
\hline
\end{tabular}

\section{Denickelification Mechanism}

Denickelification is one of the problems that found in heat exchanger tube especialy related to a hot spot that developed due to scale formation ${ }^{[6]}$. Denickelification is commonly found for Copper-Nickel alloy with high content of $\mathrm{Ni}$ such as $70 \mathrm{Cu}-30 \mathrm{Ni}$ (C71500), which is usually used as high pressure tube with low feed water flow and operated at a temperature higher than $100^{\circ} \mathrm{C}$ but it has local high heat flux. In addition, denickelification is also taken place on a heat exchanger tube where hydrocarbon flows condensated at a temperature higher than $149^{\circ} \mathrm{C}^{[7-8]}$.

Denickelification is selective leaching corrosion which normaly occured on CopperNickel alloy with high Nickel content (Cu-30Ni Cupronickel). The real condition that can generate denickelification on heat exchanger tube can be explained as follows: In the normal condition Copper-Nickle alloy is easy to form oxide passive layer when contact with oxygen. During operation, heat exchanger tubes are exposed on high temperature for a long time. Under this condition, the scale may be formed on the surface, so that direct contact between Copper-Nickel alloy and Oxygen is limited, consequently the oxide passive layer which is formed is getting thinner and thinner, finally, this passive layer is torn and can not be formed anymore. At the same time, with the presence of scale the heat transfer process under the scale is not taken place properly, consequently, hot spot is occured under the scale, it means that temperature in this area is higher than other places. As a result, the thermogalvanic reaction occurs and the agressive corrosion cell in 70Cu-30Ni Copper-Nickel alloy is getting active to desolve Copper and Nickel out from the alloy through oxidation reaction such as ${ }^{[9]}$ :

$\mathrm{Ni} \rightarrow \mathrm{Ni}^{2+}$ (oxidation of $\mathrm{Ni}$ )

$\mathrm{Cu} \rightarrow \mathrm{Cu}^{2+}$ (oxidation of $\mathrm{Cu}$ )

The following reaction then $\mathrm{Cu}^{2+}$ ions are reducted become $\mathrm{Cu}$ metal. Because the tendency of $\mathrm{Cu}^{2+}$ ions spells out from the solution is higher then $\mathrm{Ni}^{2}+$ ions, so that $\mathrm{Cu}$ metal is then redeposited again to the surface of the tubes, and some of them fill the pits that had been formed previously[10-14]. As soon as denickelification is formed, those reactions are continues to form under this scale. As the scale remains exist this reaction keep on going until the hole is formed and the tube is leaked ${ }^{[15,16]}$.

\section{CONCLUSION}

Base on the examination, testing result and discussion on the straight heat exchanger tube 301-PLE-6 it can be concluded that the material of this tube is in accordance with ASTM B-466 standard for C $71500(70 \mathrm{Cu}$ $30 \mathrm{Ni}$ copper-Nickel). Moreover, the microstructure of this tube is also appropriate to the standard microstructure of CopperNickel alloy that is austenitic a-FCC.

Denickelification phenomenon that occurs in this tube is caused by the formation of scale on the inner surface of the tube that inhibits the formation of the passive oxide layer of the alloy. This condition is also promoting the local hot spot in a certain area. As a result, thermogalvanic reaction occurs and generates selective leaching corrosion to expel Nickel elemen out and redeposit

P-ISSN 1410-3680 / E-ISSN 2541-1233 
Copper into the surrounding area. Several things can be done to prevent denickelification phenomenon, one of them is to avoid the formation of scale by conducting routine mechanical cleaning for heat exchanger tube and to control the speed of sea water flow above $1,524 \mathrm{~m} / \mathrm{s}$ so that formation of scale can be hindered[16]. This phenomenon could occur for the alloy at an operational temperature higher then $149^{\circ} C^{5-}$ 8].

\section{ACKNOWLEDGMENT}

The authors acknowledge the laboratory facility support for this work provided by B2TKS especially Material Assessment Laboratory and Failure Analysis Laboratory.

\section{REFERENCES}

[1] Kakac, Sadik \& Hongtan Liu, Heat Exchanger Selection, Rating, and Thermal Design, 2nd edition, CRC Press, Florida, 2002

[2] Savory, Eric, Lecture 8 - Basic of Heat Exchanger, Department of Mechanical and Material Engineering, University of Western Ontario, 2000

[3] Standard of Tubular Exchanger Manufactures Association, 8th edition, Tarry Town, New York, 1999

[4] Ezuber, Hosni M., dkk, Corrosion Behaviour of Copper-Nickel Alloys in Seawater Environment, NACE Paper No. MECCFEB16-9103, 16th Middle East Corrosion Conference and Exhibition

[5] Massalski, T.B \& H.Okamoto, Binary Alloys Phase Digram, $2^{\text {nd }}$ edition, American Society for Metals, Metal Park, Ohio, 1980
[6] ASM Handbook Committe, Metallography and Microstructures, Vol 9, Ninth Edition, Metal Handbook of ASM, American Society for Metals, Ohio, 2002

[7] ASTM E112, Standard Test Methods for Determining Average Grain Size, American Standard Testing of Material, 2013

[8] ASTM B466, Standard Specification for Seamless Copper-Nickel Pipe and Tube, American Standard Testing Material, 2014

[9] Liu, Jun-Fu, dkk, DeNickelification and Dezinfication of Copper Alloys in Water Environments, Microsc. Microanal., Microscope Society of America, Vol.139, Isuue 3, 2015

[10] French, David N., Metallurgical Failures in Fossil Fired Boilers, John Wiley \& Sons Inc, p.197-203, 1993

[11] Fontana, Mars G., Corrosion Engineering, $3^{\text {rd }}$. Edition, McGraw Hill Book Company, 2005

[12] Jones, Deny A., Principle and Prevention of Corrosion,...

[13] Thulukkanam, Kuppan, Heat Exchanger Design Handbook, $2^{\text {nd }}$ edition, CRC Press, 2000

[14] Lenard, D. \& R.R. Welland, Corrosion Problem with Copper-Nickel Components in Sea Water Systems, Defence Research Establishment Atlantic

[15] Cincera, Silvia, dkk, De-Nickelification of 70/30 CuproNickel Tubing in a Cooling Heat Exchanger, Journal of Failure Analysis and Prevention, Vol.12, Issue 3 hal.300-304, 2012

[16]http://www.corrosionlab.com/papers/tech nical-brief-deNickelification.htm accessed in February 2018 
(halaman ini sengaja dikosongkan) 